\title{
From Industrial to Innovation Policy
}

\author{
Luc Soete
}

Received: 20 February 2006 / Revised: 28 February 2007 /

Accepted: 14 March 2007 / Published online: 16 August 2007

(C) Springer Science + Business Media, LLC 2007

\begin{abstract}
Industrial policy has been a cornerstone of economic policy in Europe after the world war and the transformation of basic industries like coal and steel were key issues at the beginning of European integration. In the 1970s and 1990s industrial policy shifted toward support of high-tech industries. In the seventies the importance of a more systemic view came up, policy had to address the specific weaknesses of the innovation system. The Lisbon agenda finally combines competitiveness with social and environmental goals. Industry plays an important role in generating welfare and industrial policy is in different forms and sorts back, high on the agenda.
\end{abstract}

Keywords capabilities · social innovation · industrial policy · innovation system

JEL Classification $\mathrm{D} 78 \cdot \mathrm{O} 25 \cdot \mathrm{O} 33 \cdot \mathrm{O} 43$

\section{Introduction}

There is probably not one concept in the economic policy field which raises today so much controversy as industrial policy. As Pack and Saggi (2006) e.g. observe in their recent survey of industrial policy: "Few phrases elicit such strong reactions from economists and policy makers as industrial policy". There are many reasons for this, not in the least the changing global political environment with the end of the Cold War and the ensuing much wider acceptance in national policy circles, not just in small countries, of an increased reliance on the international trading and exchange in goods and services. Industrial policy at least in the definition used here: structural policies designed to strengthen the efficiency, scale and international competitiveness of domestic industrial sectors, typically contains an element of national champion, of self-reliance in bringing about economic growth and development. Not surprisingly, the concept was particularly popular in early post-war

L. Soete $(\square)$

UNU-MERIT, Keizer Karelplein 19, NL-6211 TC, Maastricht, The Netherlands

e-mail: Luc.Soete@ALGEC.unimaas.nl 
Europe and appears today particularly popular in emerging economies, and to a lesser extent some of the new European member states. In this short article we enter in some more details in the underlying analytical underpinnings of this fall and rise in popularity in industrial policy ${ }^{1}$.

Industrial policy became rapidly one of the corner stones of economic policy in the early post-war period with the need felt in many national policy circles, and most notably in those economies which had been most devastated by the war, to support a more rapid structural transformation of their economies towards internationally stronger, large industrial sectors and complexes. In Europe, it included alongside the traditional heavy, capital and scale intensive industrial sectors such as coal and steel mining - the European Coal and Steel Community (created in Paris in 1952 and dismantled (formally integrated in the EC) in 2001) - also the agricultural sector with the development of national, and in the case of Europe, a Common Agricultural Policy. Over time with the subsequent GATT rounds of international trade liberalisation, industrial policy became much more dominated by the need to assist the international "adjustment", as it was called euphemistically, of an increasing number of sectors: from the old coal and steal mining sectors to more traditional labour intensive sectors suffering increasingly from increased international competition, such as clothing and textiles, assisting those sectors by providing financial support for mergers, job displacement and cross-border integration. Viewed ex post, it might well be argued that the absolute height of belief in the virtues of a European as opposed to national industrial policy, was the development under the auspices of the European Roundtable of Industrialists (created in 1983) of the so-called Europe 1992 Single Market, resulting with the removal of internal trade barriers in further inter-sectoral shifts in various manufacturing sectors amongst European countries and as a consequence European industrial specialisation $^{2}$ and increased international competitiveness. In a first section, we turn to some of the modern economic arguments in favour of such industrial policies as exposed for instance in some of earlier work, as summarized in Dosi et al. (1990).

In a second section, we broaden the analysis away from the strong sectoral focus of industrial policy towards the much broader notion of innovation policy as it became developed over the last twenty years and gradually rose to popularity in the run up to the Lisbon summit in March 2000. Today innovation has actually emerged as one of the most popular economic terms; as often used on the Internet as the concept of GDP as a search on Google Trends illustrates ${ }^{3}$. This shift in focus cannot be seen independently from the major shifts in the world economy and in particular the much greater readiness to rely on "abroad" to bring about domestic structural change, whether under the form of international trade competition of foreign direct investment, mergers or acquisitions. At the same time the large national champions themselves have gradually transformed into truly "multinational" companies with increasingly multi-national, as opposed to national interests. This holds both for developed countries as well as for many emerging countries. It explains amongst others the eagerness with which the latter have become members of the WTO. In short, the predominance over the last 15 years, of the absolute faith in the benefits of international markets, capital and technology flows as the means of allocating sectoral resources cannot be seen outside of the broader context of the fundamental changes in the global political,

\footnotetext{
${ }^{1}$ If there is one concept in economics which seems to fit well the old BBC comedy The Fall and Rise of Reginald Perrin (Nobbs 1976), it is probably industrial policy.

${ }^{2}$ In saying so I do not want to belittle the trade creation effects of Europe 1992, see a.o. Sapir (1995).

${ }^{3}$ See e.g. Freeman and Soete (2007) where the similarity in frequency use between R\&D and productivity and innovation and GDP were noted.
} 
institutional and technological environment which took place over the same period. It is within this context that we discuss in Section 2 the emergence of innovation policy as a much broader policy framework bringing to the forefront the local systemic features anchoring so to say nationally industrial production.

We conclude with some speculative thoughts on what all this might mean for the design and future development of industrial policy. From something with a distinct negative connotation in the 1980s often resulting from some spectacular particular cases of policy failures, industrial policy under its new form of innovation policy seems to open up new policy priorities: e.g. in the design of appropriate eco-innovation as well as social welfare policies in both the developed and emerging economy world.

\section{The 1970s and 1980s: from low to high-tech industrial policy}

The early erosion in popularity of traditional industrial policy in the seventies had of course much to do with the bad press such policies were getting both in terms of the many failures of the restructured sectors and companies whereby the policy-designed aid support schemes seemed incapable of bringing about improvements in the competitiveness of such sectors/ firms and second were strongly resisted by those workers loosing their jobs as a direct consequence of the structural adjustment policies put in place. The latter job displacement was of course not just the result of increased international competition but also of the continuous technological improvements resulting in a more or less natural decline of manufacturing as share of either GDP or total employment. This deindustrialisation process was associated with the further transformation of advanced countries into more service oriented economies due to the faster growth of productivity in manufacturing than in services.

In the case of Europe, this deindustrialisation process posed more significant adjustment problems because of the particularly poor capacity of European economies to renew their industrial activities as a result of regulatory and political fragmentation. The lack of a harmonized European military sector, heavily dependent on public "high tech" procurement, took even away one of the few politically based arguments in favour of an active European industrial policy. Even today the lack of a truly European (as opposed to national) public procurement programme is often considered ${ }^{4}$ to be at the centre of Europe's lack of industrial renewal. With an EU budget ceiling of 1 to $1.27 \%$, it is of course difficult to have a European public procurement programme, whether it is in defence, so-called TransEuropean infrastructural networks or any other public utility sector.

The political awareness of having to shift industrial policy from its negative, job reducing image towards a more dynamic, "sun rise" image was of course very much inspired by the success of Japan in rapidly catching up in many industrial sectors from motor vehicles to semiconductors in the 1970s and really 1980s. At the political level, the US-Japanese semiconductor trade agreement, providing breeding space to the US industry, became one of the most clear cut examples of what appeared to become the example of a new form of strategic industrial/trade policy with major long term implications for the competitiveness of the US semiconductor industry. Hence not surprising, in Europe too, the strategic nature of industrial policy became its new justification. From an analytical point of view three different definitions of strategic became popular in the industrial policy literature: a technological one, a trade one and an industrial cluster one.

${ }^{4}$ See e.g. the Aho report from 2006 . 
The first definition of "strategic" was most closely connected to the political interpretation of the term "strategic": access to some products or technologies would contain a long term strategic advantage. This more 'military' oriented notion of strategic was probably most clearly reflected in the attempt by the US to prevent the export of "strategic" high tech products to communist countries at the time of the Soviet Union. However, and as also illustrated in the lack of success of such Concom policies in the 1980 s, it is not immediately obvious why high tech products would fall under the category of strategic products, certainly not when compared for instance to scarce natural resources of which world resources are concentrated in a number of particular countries. To the extent that new inventions and innovations are continuously subject to "creative destruction" and that knowledge is difficult to contain within firms and countries, new scientific and technological breakthroughs and the international diffusion of technology are likely to be major factors in rendering strategic high tech products relatively quickly obsolete. The case of high tech products was in other words closely based on the dominance of cumulative, increasing return features of technological advance ${ }^{5}$. For many of the most significant technologies of that time, the most typical example being microelectronics, access or better the existence of a national technological capability was considered essential for the successful transfer and effective use of technology.

The couple of high tech products which fall under this first "strategic" heading were in other words strategic in that they had an out of proportion importance in terms of their "pervasiveness", e.g., they were essential "raw material" or intermediate technological input in many capital and final consumer products, and that there were strong cumulative and increasing return features involved in the development of such technologies. National and supra-national technology policies have very much focussed on such products. One may think of the VLSI, Sematech ${ }^{6}$ and Jessi support programmes in Japan, the US or Europe.

The second notion of "strategic" increasingly used in the policy arena was the one developed in "new" trade theory by academics like Krugman (1986) and others. The argument was primarily economic, but again based on a notion of increasing returns. These were however more directly associated with the actual production of the products being traded internationally. The resulting international concentration of production of particular products in some regions/countries and not in others, would raise the possibility for "strategic" intervention, i.e. the initial stimulus to get the static and dynamic increasing returns under way within the region/country before any other region/country would do the same thing. The problem here was of course that if everybody were to develop such "strategic" policies, no one would any more reap the benefits of the scale and agglomeration economies which in theory justified such policies. From a dynamic point of view however, and following some of the subsequent "new" growth contributions in this area the picture became much more complicated. The regional or national externalities linked to the strategic product or sector could have a significant impact on growth, justifying in a more systematic way policy support for such strategic sectors. But, as contributions in the area of growth and trade illustrated, the success of such strategic policies would crucially depend on the efficiency of the dynamic sector ( $\&$ D sector) in one country compared to another. What is strategic in one country could well be anything but strategic in another. Furthermore as soon as some of the "creative destruction" feature of new technological breakthroughs and diffusion became introduced, no overall conclusion for "strategic" policy support would emerge any more (Aghion and Howitt 2006).

\footnotetext{
${ }^{5}$ See also Dosi et al. 1990.

${ }^{6}$ See Grindley et al. 1994.

嘼 Springer
} 
Trade and industrial support policies for some particular sectors which would differ very much from country to country could be said to fall under this category. One may think of European support policies for the aerospace industry. The product or sectoral focus of industrial policy would be clearly dictated by notions of the region or country's comparative or potential comparative advantage. The main practical implementation problem relates to the delineation of such sectors. No one would probably include any longer the iron and steel sector under the heading of strategic. It is clear though that both in theory and in practice the static and dynamic economies of scale have been and still are significant in this sector.

The third and probably broadest notion of strategic, did underpin directly the raison d'être of industrial policy going back to some of the early arguments of the 1950s. It could be best described with reference to the old French notion of "filières": some sectors had from a national perspective such essential forward and backward linkages in terms of material and knowledge in - and outputs, that they had become strategic to the country or region. The French automobile industry was probably the best illustration of such a sector, as would be tire making in Clermont Ferrand. One in ten Frenchmen where estimated to be somehow linked to the production and servicing of motor cars. In this very broad interpretation of industrial policy, a sector can be said to have become strategic because of its widespread infiltration of the whole economy through the large amount of vertical linkages.

All three interpretations of the notion of strategic were thought of highlighting the trade off between policies directed towards static allocative efficiency and dynamic growth efficiency. Once concepts such as increasing returns were being introduced, there appeared nothing in the mechanism leading to static allocative efficiency that would also guarantee the fulfilment of the criteria of dynamic efficiency. This point had been highlighted by many international trade and development economists long before 'new' trade and growth theory brought them in a coherent and formalized way to the attention of national policy makers. Indeed, if different commodities or sectors presented significant differences in their "dynamic strategic potential", for instance in terms of economies of scale, technical progress, learning-by-doing, etc., international specialisations which appeared efficient in terms of static comparative advantage criteria could well generate in the long run virtuous or vicious circles of technological backwardness.

What the debate about "strategic" trade policy in the 1980s brought to the forefront is that in contrast to the previous literature, arguments about the existence of such possible trade-offs were more than a special case related to infant industries. They were, once account was taken of the continuous nature of technological change, with its various dynamic increasing returns and cumulative features, more likely to be the general condition of any economic system. In so far as the actual process of production in firms, regions or countries was closely associated with the existence of technological capabilities in such firms, regions or countries, mechanisms leading to specialisation in production did also have a clear and significant dynamic counterpart in that they also would lead to specialisation in technological skills and capabilities. The potential for such dynamic technological specialisation would in other words be very much different between technologies and sectors. The identification and support of "strategic" technologies or sectors, even though not justified on the basis of static allocative efficiency, could then well be justified from a dynamic perspective (in terms of long term output and productivity growth, innovativeness, etc.). Not surprisingly these are the insights which currently find their biggest application and support in the design of industrial policies in emerging economies. 


\section{The 1990s: shifting towards more systemic policy views}

Over the past ten to fifteen years, there has been a gradual shift in the understanding of the relationships between research, innovation and socio-economic development. Sectoral explanations either of the technology push or the demand pull kind have gradually lost in policy influence. Instead, it is now widely recognised that economic growth and well-being is founded on a much broader, well-functioning "knowledge and innovation system", in which all actors perform well. The concept of a National (or Regional) Innovation System emerged originally in the late 80 's and was coined by Freeman to describe the much broader congruence in the Japanese society between all sorts of institutional networks in both "private and public sectors whose activities and interactions initiate, import, modify and diffuse new technologies" (Freeman 1987). Lundvall, on his side, emphasized in a broadly similar manner "the elements and relationships which interact in the production, diffusion and use of new, and economically useful, knowledge... and are either located within or rooted inside the borders of a nation state" (Lundvall 1992), whereas Nelson would more specifically focus on the "set of institutions whose interactions determine the innovative performance of national firms" (Nelson 1993). It clearly put the emphasis away from the sectoral dimension towards the much broader national institutional framework within which firms and other organisations operated and which appeared of crucial importance to the speed, extent and success by which innovations got introduced and diffused in the economy.

A common feature of all such systems - regional, national and trans-national — was the fact that firms rarely if ever innovate alone. As those "innovation scholars" had been at pains to point out for many years there is need for a constant interaction and co-operation between the innovating firm and its external environment, which in the optimal case leads to a virtuous learning circle of better exploitation of available knowledge. As Richard Nelson (1993) noted: "to orient R\&D fruitfully, one needs detailed knowledge of its strengths and weaknesses and areas where improvements would yield big payoffs and this type of knowledge tends to reside with those who use the technology, generally firms and their customers and suppliers. In addition, over time firms in an industry tend to develop capabilities . . . largely based on practice."

The fact that the national innovation systems of countries would show marked differences, associated with their individual paths of specialisation in production, had of course also obvious policy implications. External intervention could indeed be desirable or even necessary but had to be informed by local conditions and based on the study of innovation processes, organisations and institutions and their interactions over relatively extended periods. It became crucial to identify which elements of the system were subject to inertia so that particular deficiencies could be addressed. Authors in the national systems of innovations literature tradition would refer to the "dynamic co-evolution of knowledge, innovations, organisations and institutions". From a systemic perspective, it is often the weakest chain, which is the most critical one for economic growth and development, and hence also for policy intervention.

The idea that there is something to learn from institutional arrangements and policies in other, more "advanced" environments, as exemplified in the subsequent European focus on the knowledge gap with the US, and that systematic comparative studies would be a useful tool in this respect, was of course also not a new one. Alexander Gerschenkron pioneered this kind of comparative country study. As he pointed out, some countries are at the technological frontier, while others lag far behind. Although the technological gap between the frontier country and the laggard would represent "a great promise" for the latter (a 
potential for higher growth through imitating frontier technologies), there were also various problems that would prevent backward countries from reaping the potential benefits to the full. Gerschenkron actually argued that if one country succeeded in embarking on an innovation-driven growth path, others might find it increasingly difficult to catch up. His favourite example was Germany's attempt to catch up with Britain a century ago. When Britain industrialized, technology was relatively labour intensive and small scale. But in the course of time technology became more capital and scale intensive, so when Germany entered the scene, the conditions for entry had changed considerably. Because of this, Gerschenkron argued, Germany had to develop new institutional instruments for overcoming these obstacles, above all in the financial sector, "instruments for which there was little or no counterpart in an established industrial country" (Gershenkron 1962). He held these experiences to be valid also for other technologically lagging countries ${ }^{7}$.

In this context Abramovitz (1986) had introduced also, already in the 1950s, the notions of technological congruence and social capability to discuss what he called the "absorptive capacity" of late-comers. The concept of technological congruence referred to the degree to which leader and follower country characteristics were congruent in areas such as market size, factor supply, etc. The concept of social capability pointed to the various efforts and capabilities that backward countries possessed in order to catch up, such as improving education, infrastructure and technological capabilities (R\&D facilities, etc.). He explained the successful catching up of Western Europe vis-à-vis the USA in the post-war period as the result of both increasing technological congruence and improved social capabilities. As an example of the former he mentioned explicitly how European economic integration led to the creation of larger and more homogenous markets in Europe, facilitating the transfer of scale-intensive technologies initially developed for US conditions. Improved social capabilities on the other hand were reflected in such other factors as the general increase in educational levels, the rise in the share of resources devoted to public and private sector $\mathrm{R} \& \mathrm{D}$ and the success of the financial system in mobilizing resources for change. In a similar vein the failure of many developing countries to exploit the same opportunities is commonly accounted for by their lack of technological congruence and missing social capabilities (e.g. education, financial system).

The point here is that concepts such as "technological congruence" and "social capability" appear to be important policy notions which might be helpful in addressing the systemic "success" or "failure" of science, technology and innovation policies. But the notions and concepts developed originally by Gerschenkron and Abramovitz provide an even stronger policy handle than originally thought by national systems of innovation theorists. As highlighted elsewhere (Soete 2005), four factors appear at the outset essential for the functioning of a national system of innovation and could be considered as the essential features to bear in mind when designing appropriate innovation policies.

First there is the investment of the country in social and human capital: the cement, one may argue, that holds the knowledge and innovation systems together. It is incorporated in a number of knowledge generating institutions in the public as well as the private sector such as universities, polytechnics and other skills' training schools. Social and human capital is of course also likely to be involved in the creation of new innovations and the diffusion of those innovations throughout the economic system. With the development of 'new growth' models in the economics literature, the role of education and learning in continuously generating, replacing and feeding new technology and innovation has

${ }^{7}$ For a more in depth analysis of these historical contributions to modern catching up growth theory see Fagerberg (2002). 
received much more emphasis ${ }^{8}$ over the last decade. An initial stock of human capital in a previous period is likely to generate innovation growth and productivity effects, downstream as well as upstream with lots of 'spill-overs' and positive 'externalities', affecting other firms, regions and countries.

Higher education is itself crucial for the continuous feeding of fundamental and applied research. Many new growth models have tried to build in a more complex fashion such impacts, giving prime importance not just to education itself, but also to its by-products such as research and innovation. The second central node of any system of innovation is hence not surprisingly the research capacity of a country or region and the way it is closely intertwined with the country's higher education system. From a typical "national" innovation system perspective, such close interaction appears important; from an international perspective the links might be much looser, with universities and research institutions being capable of attracting talent world wide.

In most technology growth models, these two nodes form the essential "dynamo effects" (Dosi 1988) or "yeast" and "mushroom" effects (Harberger 1998) implicit in the notion of technological change. Knowledge and human capital act like yeast to increase productivity relatively evenly across the economy, while other factors such as a technological breakthrough or discovery suddenly mushroom to increase productivity more dramatically in some sectors than others.

The third "node" holding knowledge together within the framework of a national system of innovation is, maybe surprisingly, geographical proximity. The regional clustering of industrial activities based on the close interactions between suppliers and users, involving learning networks of various sorts between firms and between public and private players, represents a more flexible and dynamic organisational set-up than the organisation of such learning activities confined within the contours of individual firms. Regional or local learning networks can allow for much more intensive information flows, mutual learning and economies of scale amongst firms, private and public knowledge institutions, education establishments, etc. Some innovation management authors (Chesbrough 2003) like to refer here to the notion of "open innovation". The technological and innovative performance of firms is what can be most directly measured to approximate the degree of success of such clustering.

In a well-known study Putnam (2000) compares the impact of Silicon Valley and Route 128 in the US. He cites Silicon Valley in California where a group of entrepreneurs, helped by research effort in the local universities, contributed to the development of a world centre of advanced technology. As he puts it: 'The success is due largely to the horizontal networks of informal and formal cooperation that developed among fledgling companies in the area'. By contrast, in the Route 128 corridor outside Boston, lack of inter-firm social capital has led to a more traditional form of corporate hierarchy, secrecy, self-sufficiency, and territoriality. The comparison shows that the innovativeness and technological performance of firms strongly depends on close interaction between them.

In addition to human capital, research and the related phenomenon of local networks, and particularly inter-firm networking, the fourth and last notion essential to any innovation system approach is the 'absorptive capacity' of firms, clients and consumers in a particular region or country. The ability of companies to learn will of course in first instance depend on their internal capabilities represented by the number and level of scientifically and technologically qualified staff. Firms must do enough R\&D to be economically dynamic and to have the 'absorptive capacity' to conduct a professional dialogue with the public

\footnotetext{
${ }^{8}$ See Bassanini and Scarpetta (2001) and a more recent exploration by Vandenbussche et al. (2006). 
Fig. 1 A national system of innovation taxonomy

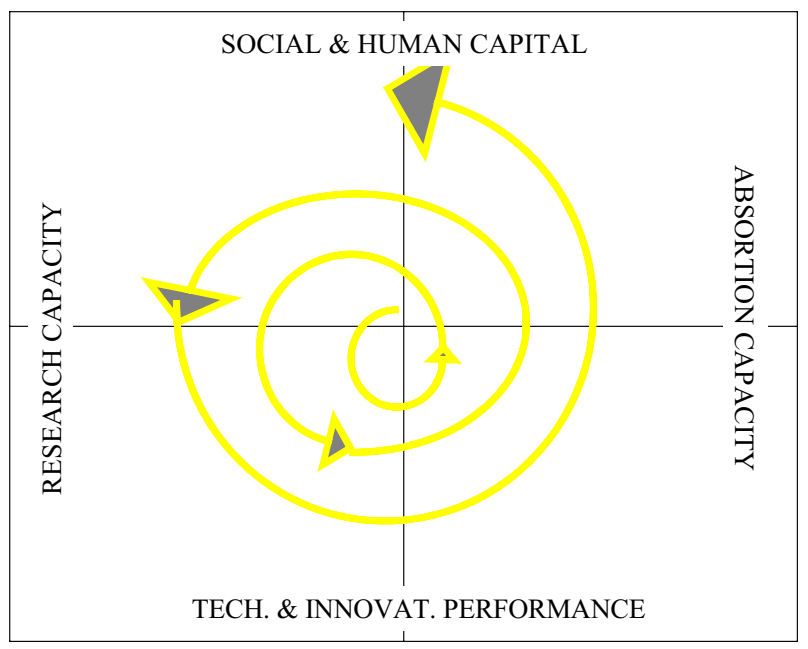

research sector and other external sources of knowledge. At the same time, consumers, clients, and citizens might be very open to new designs, products, even ideas, enabling rapid diffusion of such new products created by $R \& D$ in knowledge-intensive sectors, or very conservative, resistant to change and suspicious of novelty. The absorptive capacity amongst countries, regions, even suburbs, varies dramatically.

Schematically Figure 1 illustrates the growth dynamics associated with such an ideal, virtual national innovation system: the four key nodes suggested here can be represented in a simple taxonomic way, opposing the relative importance given in science, technology and innovation policy to supply versus demand on the one hand and users versus creators factors on the other. Supply will generally be dominated by public resources, demand by private resources. The focus on users will be generally characterized by broad, economy wide features, reflecting the impact of the diffusion of technologies; the focus on creators will be generally more specific. The four key elements suggested above can be represented as elements of a virtual circle mutually reinforcing each other with in the end a positive overall impact on competitiveness and sustainable growth. From this perspective, it is in the interactions between these four constituents that the most interesting and efficient set of science, technology and innovation policy initiatives can be found.

\section{Conclusions}

The last 60 years has seen a major shift in the recognition amongst policy makers about the usefulness and effectiveness of industrial policy. We highlighted in the introduction the importance of the global political, economic and technological transformations which took place worldwide since the fall of the Berlin wall. No doubt there is also a close relationship between the effectiveness of industrial policy and a country's level of development. Advanced countries have all witnessed over the 90's an acceleration in the process of deindustrialisation with a more rapid growth in services following the diffusion of information and communication technologies (Petit and Soete 2001). The dominance of the industrial sector remains of course structurally very different between countries such as Germany or France from countries such as the UK or The Netherlands. Not surprisingly the 
biggest economic concerns with respect to deindustrialisation emerge from the large countries, which are still dominated by strong industrial presence, such as France and Germany. But probably more interesting in this context are the cases of small countries which have witnessed rapid deindustrialisation over the 1990s but at the same time, nevertheless witnessed rapid growth in the industrial value added per worker, such as Austria or Finland. The upgrading and industrial renewal has been relatively successful in those countries even if it has failed to provide sufficient new employment opportunities to completely offset the deindustrialisation trend. The growth in industrial productivity, however, was sufficient to redistribute part of such gains for employment growth in service sectors and other low productivity social services. At the other spectrum countries such as Germany or The Netherlands, witnessed most typically the Baumol Effect ${ }^{9}$ with relatively low productivity growth associated with the further rise in service activities but strong employment growth in the 1990s. Whether such a trend is sustainable is highly questionable, as recent evidence illustrates. In emerging countries, similar trends have taken place but as yet less well noted. As Kaplinsky (2005) has shown there are increasingly also signs of deindustrialisation in countries such as China and India.

Since Lisbon though, there is broad recognition though that a sectoral focus on international competitiveness needs ultimately to be complemented by a much broader look at the systemic "congruence" between various other policy domains which are of particular relevance to the nation or in the case of Lisbon, European growth and industrial dynamics. The relevant policy term coined here is, as we discussed in section 2, the national system of innovation. Over the last ten to twenty years the institutional matching between the various components of such countries' national system of innovation has become gradually weaker, not in the least because of the globalisation pressures, which have acted differently on each of those components. In a recent paper (Soete 2005), I have dubbed the growing mismatch between the key public and private knowledge components of the national system of innovation, the "Dutch knowledge disease" $"$ From this perspective the innovation policy focus should be on the "crowding in" in Europe of such knowledge based activities both in the private and public sector.

This being said, the contribution of an internationally competitive industrial sector remains a crucial asset for economic growth and more broadly social welfare. A rapidly growing industrial sector as in many emerging economies provides major opportunities for social re-distributional policies and for addressing the problems of urban and rural poverty and inequality. A declining industrial sector in advanced countries by contrast, responsible for the biggest component of economic welfare (as measured through value added per worker) in an economy, will raise questions about the sustainability of such countries' social and welfare models. It remains therefore somewhat of a paradox that at a time that emerging economies are discovering the benefits of industrial policy, the concept has basically disappeared from the official policy language in some advanced countries.

Turning to the future, it seems that one of the central policy questions in the rich, advanced country world, is to what extent industry can continue to play its role as

\footnotetext{
${ }^{9}$ See Baumol and Bowen's 1966 work and, for instance, also Inklaar et al. (2007).

${ }^{10}$ The phenomenon of "Dutch knowledge disease" (Soete 2005), highlights a lack of knowledge renewal in both industrial and services sectors based on a dual phenomenon of "crowding out". First, a crowding out of basic research in the private sector, with for instance many domestic champions having drastically, under international pressure, cut back their own privately funded fundamental research activities. And, secondly, a crowding out of more applied and market driven research in universities as a result of domestic competition putting a strong premium on academic, basic research.
} 
frontrunner in such areas as the environment and social conditions within an increasingly competitive environment without a strong domestic industrial policy. There is already today a large gap between the environmental awareness, introduction of environmental-friendly technologies (end-of pipeline and clean technologies) in industry and the same awareness and diffusion of such goods with final consumers. The emissions of industry have in some areas been substantially reduced and are now subject to emissions schemes providing internal incentives schemes for further reduction in, e.g., $\mathrm{CO} 2$ emissions. By contrast the results on the consumer side have been much less impressive. At the moment, it could even be argued that when the consumer enters the factory as worker/employee he enters an environmentally more sophisticated and fine tuned world than when he gets back at home. The consumer's lagging awareness of environmental issues has as a consequence created a gap with the demand for environmental friendly products. The question can be raised how long European industry will be able to maintain such a front running position in a less environmentally friendly regulated world market with too few domestic consumers ready to contribute in their consumption behaviour to the additional costs. The same argument holds for the social conditions. Here too enterprises (not just industry) are being forced to behave as frontrunners in a socially sophisticated way, providing social provisions, working conditions, human resources and training, by which they become as if it were model places: islands of well regulated and controlled social conditions. Outside of the enterprise environment, citizens are increasingly confronted with insecurity, abuse, lack of social contacts, declining family values, etc.

In short, industry will continue to play a strong role in generating welfare both in rich and poor countries. In doing so industry in the advanced countries, and in particular in Europe, has been an engine of progress way beyond the dramatic increase in material progress it generated in post-war Europe but bringing about also the means to achieve social progress. With increased globalisation, one can only hope that industry will be an engine for the spreading of social progress, environmentally friendly technologies and ecoinnovations world wide. Industrial policy in different forms and sorts is back, high on the agenda.

Acknowledgements In writing this paper I have benefited from seminar discussions amongst others at Centre d'Analyse Stratégique, Séminaire Lisbonne 2, 20 November 2006, and the IFRI Conference Europe in global, innovation-based competition, 16 January 2007. I am grateful to Philippe Aghion, Lars-Hendrik Röller and Frédérique Sachwald for critical comments.

\section{References}

Abramovitz, M., "Catching up, forging ahead and falling behind,” Journal of Economic History, vol. 46(2), pp. 385-406, 1986.

Aghion, P. and Howitt, P., "Joseph Schumpeter lecture; appropriate growth policy: a unifying framework", Journal of the European Economic Association, vol. 4(2-3), pp. 269-314, 2006.

Aho, E., et al., Creating an innovative Europe: report of the independent expert group on R\&D and innovation appointed following the Hampton Court Summit, Brussels: European Commission, 2006.

Baumol, W.J. and Bowen, W.G., Performing arts: the economic dilemma. New York: The Twentieth Century Fund, 1966.

Bassanini, A. and Scarpetta, S., Does human capital matter for growth in OECD countries? OECD Economics Department Working Paper no. 2001-8. Paris: OECD, 2001.

Chesbrough, H., Open Innovation: The New Imperative for Creating and Profiting from Technology. Harvard Business School Press: Boston, 2003. 
Dosi, G., "Sources, procedures, and microeconomic effects of innovation". Journal of Economic Literature, vol. 26(3), pp. 1120-1171, 1988.

Dosi, G., Pavitt K., and Soete, L. The Economics of Technical Change and International Trade. Harvester Wheatsheaf: New York, 1990.

Fagerberg, J., Technology, Growth and Competitiveness: Selected Essays. Edward Elgar: Cheltenham, 2002.

Freeman, C., Technology Policy and Economic Performance: Lessons from Japan. Pinter: London, 1987.

Freeman, C. and Soete, L., Developing science, technology and innovation indicators: What we can learn from the past, UNU-MERIT Working paper 2007-001, 2007.

Gershenkron, A., Economic Backwardness in Historical Perspective. Belknap Press of Harvard University Press: Cambridge, 1962.

Grindley, P., Mowery, D.C., and Silverman, B. "SEMATECH and Collaborative Research: Lessons in the Design of High-Technology Consortia”. Journal of Policy Analysis and Management. vol. 13(4), pp. 723-758, 1994.

Harberger, A., "A vision of the growth process", American Economic Review, vol. 88(1), pp. 1-32, 1998.

Inklaar, R., Timmer, M.P., and Van Ark, B. "Mind the Gap! International Comparisons of Productivity in Services and Goods Production". German Economic Review, vol. 8(2), pp. 281-307, 2007.

Kaplinsky, R., Globalization, poverty and inequality: between a rock and a hard place. Polity Press: Cambridge, 2005.

Krugman, P., Strategic Trade Policy and the New International Economics. MIT Press: Cambridge, 1986.

Lundvall, B.-Å., National Systems of Innovation: Towards a Theory of Innovation and Interactive Learning. Pinter: London, 1992.

Nelson, R.R., National Systems of Innovation: A Comparative Study. Oxford University Press: Oxford, 1993.

Nobbs, D., The Fall and Rise of Reginald Perrin. Penguin: Harmondsworth, 1976.

Pack, H. and Saggi, K., Is there a case for industrial policy?: A critical survey". The World Bank Research Observer. vol. 21(2), pp. 267-297, 2006.

Petit, P. and Soete, L., Technology and the Future of European Employment. Edward Elgar: Cheltenham, 2001.

Putnam, R., Bowling Alone: The Collapse and Revival of American Community. Simon \& Schuster: New York, 2000.

Sapir, A., Europe's single market: The long March to 1992, CEPR Discussion Paper, No.1245. CEPR: London, 1995.

Soete, L., "On the dynamics of innovation policy: A Dutch perspective," in De Gijsel, P. and Schenk, H. (eds.), Multidisciplinary Economics. Dordrecht, (Springer), 2005.

Vandenbussche, J., Aghion, P., and Meghir C. "Distance of technological frontier and composition of human capital". Journal of Economic Growth, vol. 11(2). pp. 97-127, 2006. 